\title{
Analysis of River Water Along Klang Valley to Evaluate the Prevalence of Antibiotics Resistant Strains within Urbanized Areas of Selangor, Malaysia ${ }^{\dagger}$
}

\author{
Sajna Keeyari Purayil 1,*, Saasidran A/L Murugan 1, Paulraj Ponnaiah 1, Yi Ting Lee 1, Sajeesh \\ Pattammadath ${ }^{1}$, Mohamed Javad P.T. ${ }^{1}$ \\ 1 School of Biosciences, Faculty of Medicine, Bioscience and Nursing, MAHSA University Bandar Saujana Putra, 41200, \\ Selangor, Malaysia \\ * Correspondence: sajna@mahsa.edu.my; \\ $\uparrow$ Presented at International e-Conference on Bioengineering for Health and Environment (ICBHE 2020)
}

Received: 5.07.2020; Revised: 10.07.2020; Accepted: 12.07.2020; Published: 15.07.2020

\begin{abstract}
The determination of antibiotic-resistant bacteria in Klang river water in Klang valley is performed as the river exposed to various environments. The analysis is performed through enumeration, isolation, and identification process. The water samples were obtained from the origin of the river, housing region, and hospital region. The coliforms obtained through enumeration and identification was then used to determine antibiotic sensitivity, minimum inhibitory concentration (MIC), and minimal bactericidal concentration (MBC). The level of coliforms was indicated through the most probable number (MPN), which 70 MPN per $100 \mathrm{ml}$ of river water in the origin of the river while housing and hospital regions showed more than 1600 MPN per $100 \mathrm{ml}$ of river water. The results obtained from the antibiotic sensitivity test showed that the degree of resistance of coliforms is varied in different regions. The zone of inhibition to ampicillin and tetracyclin for coliforms in housing regions is $20 \mathrm{~mm}$, while the coliforms in the hospital region are $6 \mathrm{~mm}$ and $7 \mathrm{~mm}$, respectively. The overall results showed that the level of coliforms and the antibiotic sensitivity of coliforms are different in various regions. The coliforms in the hospital region are more resistant to antibiotics compared to the housing region.
\end{abstract}

Keywords: river water; antibiotics resistant strains; Selangor.

(C) 2020 by the authors. This article is an open-access article distributed under the terms and conditions of the Creative Commons Attribution (CC BY) license (https://creativecommons.org/licenses/by/4.0/).

\section{Funding}

This research received no external funding.

\section{Acknowledgments}

This research has no acknowledgment.

\section{Conflicts of Interest}

The authors declare no conflict of interest. 